\section{Bianca Schmid}

Regina Bernal

Nilza Nunes Silva

Departamento de Epidemiologia. Faculdade de Saúde Pública. Universidade de São Paulo. São Paulo, SP, Brasil

\section{Correspondence: \\ Bianca Schmid \\ Av. Dr. Arnaldo, $715,2^{\circ}$ andar \\ Instituto Cerqueira Cesar \\ 01246-904 São Paulo, SP, Brasil \\ E-mail: bschmid@usp.br}

\section{Self-medication in low-income adults in Southeastern Brazil}

\begin{abstract}
OBJECTIVE: To estimate the self-medication prevalence in low-income adults and identify associated factors.

METHODS: Data from a population survey performed in São Paulo municipality, Southeastern Brazil in 2005, were used. The sample strategy included two domains, favelas and non-favelas, with clustered sampling performed in two stages with a total of 3,226 eligible individuals. In addition to sociodemographic and economic characteristics, the multiple logistic regression included: use of medicines in the 15 days preceding interview, access to medicines (free, purchased or other) and type of morbidities treated (chronic or acute).
\end{abstract}

RESULTS: The proportion of self-medication was $27 \%$ to $32 \%$. Self-medication was strongly associated with acute morbidity, ability to purchase medicines, age less than 47 years and the medicine group that acts on the central nervous system. The medicinal group that acts on the central nervous system was the most common utilized in self-medication.

CONCLUSIONS: Free access to medicines was shown to be a protective factor for self-medication. The distribution of medicines and appropriate health care should be considered when providing patient counseling and for reducing health risks from irrational medicine use.

DESCRIPTORS: Self Medication, economics. Drugs of Continuous Use. Socioeconomic Factors. Cross-Sectional Studies.

\section{INTRODUCTION}

Self-medication consists of the "selection and use of medicines by people to treat self-diagnosed diseases or symptoms and should be understood as one of the elements of self-care". ${ }^{a}$ According to Pelicioni, ${ }^{b}$ responsible self-medication can bring savings to the individual and for the health system, avoiding over use of the available services. Nonetheless, irrational self-medication increases the risk of adverse events and of masking diseases, which can delay correct diagnosis. Treatments that are more complex, invasive, expensive and difficult to recover from can become necessary.

Innumerable factors lead to the irrational use of medications, such as the practice by Brazilian pharmacies of indiscriminate selling of medications, the unrestricted advertising of medicines in the media, inadequate health system and high cost of private health plants and private consultations. ${ }^{a}$ Schenkel et

a World Health Organization. The role of the pharmacist in self medication care. Report of the $4^{\circ}$ WHO Consultive Group on the role of the Pharmacist. The Hague, The Netherlands 26-28 August 1998. Geneva; 1998

b Pelicioni AF. Padrão de consumo de medicamentos em duas áreas da Região Metropolitana de São Paulo, 2001-2002 [master's dissertation]. São Paulo: Faculdade de Saúde Pública da USP; 2005. 
$\mathrm{al}^{7}$ confirmed that self-medication also occurs in the higher social classes and in developed countries that have better organized health systems. In a population study in Santa Maria, Southern Brazil, Vilarino et $\mathrm{a}^{9}$ found a positive association between education level and self-medication. In a review about the use of medicines among the elderly population, Rozenfeld ${ }^{5}$ found that, despite an evident relationship between increased age and greater number of medicines utilized, self-medication among the elderly is less (18\%) than in younger groups $(40 \%)$.

This study aimed to estimate the prevalence of selfmedication and identify associated factors among low-income adults.

\section{METHODS}

The study utilized the database from the research "Experience of access to medicines and generics among the low-income population - São Paulo Municipality, 2005", performed with people greater than 40 years. ${ }^{\text {c }}$

The population survey was performed in São Paulo municipality, Southeastern Brazil, in 2005, through random probabilistic sampling in two domains: favelas and non-favelas, with cluster sampling in two stages, with distribution proportional to size. In the first stage, the census sectors were randomly selected and, in the second, households. The questionnaires were administered by trained interviewers, under the supervision of a field coordinator. Of the 3,226 eligible individuals, 305 were not found or refused to respond, for a loss of $12.6 \%$ of the sample. In total, 2,921 responded to the study, and 1,973 of them (68\%) responded that they utilized medications in the 15 days preceding the interview, of which 982 lived in favelas and 991 did not.

Use of medications was defined as needing medication and having had access to at least one of them.

Self-medication was defined as the use of at least one medication that was not indicated by a doctor or dentist and was indicated by pharmacists, pharmacy receptionist or others.

The association was estimated between self-medication and sociodemographic variables (sex, age, work, education, income), access to medications (only free: medicines exclusively obtained for free in health posts or government programs; only purchased: medicines exclusively purchased by the interviewee; and mixed access) and type of morbidity (only chronic: medicines only treated health problems in a continuous manner without an end date; only acute: medicines used to only treat momentary problems; and chronic and acute: medicines to treat both situations). Work was defined as the performance of some type of remunerated activity at the time of interview. Retired people, housewives and those on pensions were classified as people that do not work.

Multiple logistic regression ${ }^{d}$ was utilized $\log \left\{\frac{\pi(x)}{1-\pi(x)}\right\}=\beta_{1}+\beta_{2} x_{2}+\ldots+\beta_{p} x_{p}$, where $\pi(x)$ represents the probability (between 0 and 1 ) of an individual self-medicating given the characteristics $\mathrm{x}_{\mathrm{i}}(\mathrm{sex}$, age, employment, type of access, type of morbidity and therapeutic class). The variables used in planning the sample were utilized in the statistical analysis. The variables income and education were not included in the model because they are directly associated with type of access. The evaluation of the adjusted model used a probability of up to 0.5 as a cut-off point to classify the individuals as 0 (non-self-medication), and the other were classified as 1 (self-medication).

The medications used by the participants were classified by the provider or system, ${ }^{10}$ according to the 14 categories proposed by World Health Organization.

There were 14 dichotomous variables created, each representing the use or non-use of medicines in a corresponding class.

Each participant signed a voluntary informed consent form, at the end of each questionnaire. The study was approved by the Ethics Committee of the Public Health School of the University of São Paulo, under research protocol number 993 , on $08 / 12 / 2003$.

\section{RESULTS}

The majority of medication users were female $(65 \%)$, $44 \%$ were between 48 and 62 years, $60 \%$ did not work, $71 \%$ were between one and eight years of education and $\approx 30 \%$ had a monthly income of up to $\mathrm{R} \$ 300.00$. The proportion of self-medication was almost $30 \%$. Close to $46 \%$ reported obtaining medicines exclusively through purchase, and about $39 \%$ used medication only for chronic diseases. The majority of participants used medicines for the cardiovascular system (Class C) and central nervous system (Class N). Less than $10 \%$ of users reported using medicines from the other class (Table 1).

No significant difference was observed between the sexes. Age was associated with self-medication, and those with less than 47 years most frequently selfmedicated, with a proportion between $38 \%$ and $48 \%$.

\footnotetext{
c Silva NN. Experiência de acesso da população de baixa renda a medicamentos e os genéricos, Município de São Paulo, 2005. São Paulo: Fapesp; 2005. [Scientific report].

${ }^{d}$ Paula GA. Modelos de Regressão com apoio computacional [doctoral thesis]. São Paulo: Instituto de Matemática e Estatística da USP; 2004.
} 
Table 1. Proportion and measures of precision for the low-income adult population, according to sociodemographic variables and medication use. São Paulo, Southeastern Brazil, 2005.

\begin{tabular}{|c|c|c|c|c|}
\hline Variable & $\mathrm{n}$ & $\%$ & $95 \% \mathrm{Cl}$ & Deff \\
\hline \multicolumn{5}{|l|}{ Sex } \\
\hline Female & 1,307 & 65.2 & $63.36 ; 67.08$ & \multirow{2}{*}{0.94} \\
\hline Male & 666 & 34.8 & $32.92 ; 36.64$ & \\
\hline \multicolumn{5}{|l|}{ Age (years) } \\
\hline 40 to 47 & 645 & 30.7 & $27.71 ; 33.67$ & 2.15 \\
\hline 48 to 62 & 870 & 43.7 & $40.84 ; 46.56$ & 1.70 \\
\hline 63 to 95 & 458 & 25.6 & $22.66 ; 28.54$ & 2.32 \\
\hline \multicolumn{5}{|l|}{ Employment ${ }^{\mathrm{a}}$} \\
\hline No & 1,129 & 60.4 & $57.06 ; 63.72$ & \multirow{2}{*}{2.38} \\
\hline Yes & 831 & 39.6 & $36.23 ; 42.94$ & \\
\hline \multicolumn{5}{|l|}{ Education (years) } \\
\hline Illiterate & 324 & 14.7 & $12.72 ; 16.72$ & 1.63 \\
\hline Between 1 and 8 & 1,405 & 71.4 & $68.50 ; 74.34$ & 2.15 \\
\hline 9 or more & 233 & 13.9 & $10.97 ; 16.73$ & 3.55 \\
\hline \multicolumn{5}{|l|}{ Income (Reais) } \\
\hline No income & 521 & 27.4 & $24.82 ; 30.00$ & 1.72 \\
\hline Up to 300 & 595 & 29.7 & $26.86 ; 32.62$ & 2.05 \\
\hline From 301 to 600 & 467 & 22.3 & $20.21 ; 24.45$ & 1.34 \\
\hline More than 600 & 390 & 20.5 & $18.16 ; 22.86$ & 1.75 \\
\hline \multicolumn{5}{|l|}{ Self-medication } \\
\hline No & 1,411 & 70.2 & $67.22 ; 73.14$ & \multirow{2}{*}{2.16} \\
\hline Yes & 562 & 29.9 & $26.96 ; 32.88$ & \\
\hline \multicolumn{5}{|l|}{ Type of access } \\
\hline Only free & 634 & 28.9 & $26.05 ; 31.81$ & 2.06 \\
\hline Only purchased & 847 & 45.7 & $42.79 ; 48.63$ & 1.76 \\
\hline Mixed access & 492 & 25.4 & $23.39 ; 27.31$ & 1.05 \\
\hline \multicolumn{5}{|l|}{ Type of morbidity } \\
\hline Only chronic & 792 & 40.1 & $36.78 ; 42.00$ & 1.48 \\
\hline Only acute & 716 & 36.3 & $34.00 ; 39.26$ & 1.53 \\
\hline Chronic and acute & 465 & 23.6 & $22.76 ; 27.18$ & 1.35 \\
\hline \multicolumn{5}{|l|}{ ATC Class } \\
\hline A - Alimentary tract and metabolism & 543 & 27.1 & $24.16 ; 30.04$ & 2.33 \\
\hline B - Blood and blood forming organs & 18 & 0.1 & $0.00 ; 0.69$ & 1.98 \\
\hline C - Cardiovascular system & 991 & 50.3 & $47.56 ; 53.04$ & 1.66 \\
\hline D - Dermatologicals & 36 & 1.5 & $0.95 ; 2.05$ & 1.05 \\
\hline G - Genito-urinary system and sex hormones & 48 & 2.4 & $1.77 ; 2.95$ & 1.03 \\
\hline $\begin{array}{l}\mathrm{H} \text { - Systemic hormonal preparations, excluding sex hormones } \\
\text { and insulins }\end{array}$ & 68 & 3.5 & $2.52 ; 4.48$ & 1.68 \\
\hline J - Antiinfectives for systemic use & 143 & 6.9 & $5.92 ; 7.88$ & 1.50 \\
\hline L - Antineoplastic and immunomodulating agents & 14 & 0.9 & $0.51 ; 1.29$ & 1.67 \\
\hline M - Musculo-skeletal system & 412 & 21.8 & $19.84 ; 23.76$ & 1.34 \\
\hline $\mathrm{N}$ - Nervous system & 816 & 41.2 & $38.26 ; 44.14$ & 2.07 \\
\hline P - Antiparasitic products, insecticides and repellants & 25 & 1.2 & $0.61 ; 1.80$ & 1.51 \\
\hline R - Respiratory system & 153 & 7.4 & $5.93 ; 8.87$ & 1.64 \\
\hline S - Sensory organs & 35 & 1.6 & $1.01 ; 2.19$ & 1.21 \\
\hline
\end{tabular}

Deff = Design effect; ATC: Anatomical Therapeutic Chemical; 95\%Cl: 95\% confidence interval

a In 13 interviews, economic activity was not identified.

${ }^{\text {b }}$ Education was not reported in 11 interviews. 
Individuals that worked tended to self-medicate more than others (unemployed, retired, pensioners and housewives). Between $16 \%$ and $28 \%$ of illiterate people reported self-medication and the higher education levels were associated with greater self-medication. The proportion of self-medication also increased with income. Access to medicines, by purchase or mixed, was strongly associated with the outcome, which was less frequent among those that obtained free medicines (3\% to $7 \%$ ). The type of morbidity for which the individual used the medication was also significantly associated with self-medication. Between 53\% and 63\% of those using medicines exclusively for acute diseases reported self-medication (Table 2).

Table 2. Prevalence of self-medication in the low-income adult population, according to sociodemographic variables and medication use. São Paulo, Southeastern Brazil, 2005.

\begin{tabular}{|c|c|c|}
\hline \multirow{2}{*}{ Variable } & \multicolumn{2}{|c|}{ Self-medication } \\
\hline & $\%$ & $95 \% \mathrm{Cl}$ \\
\hline \multicolumn{3}{|l|}{ Sex } \\
\hline Female & 26.9 & $24.17 ; 29.79$ \\
\hline Male & 27.9 & $24.16 ; 31.93$ \\
\hline \multicolumn{3}{|l|}{ Age (years) } \\
\hline 40 to 47 & 43.4 & $38.5 ; 48.3$ \\
\hline 48 to 62 & 25.9 & $21.5 ; 30.3$ \\
\hline 63 to 95 & 20.2 & $15.8 ; 24.4$ \\
\hline \multicolumn{3}{|l|}{ Employment } \\
\hline No & 24.2 & $20.9 ; 27.3$ \\
\hline Yes & 38.2 & $33.6 ; 42.7$ \\
\hline \multicolumn{3}{|l|}{ Education (years) } \\
\hline Illiterate & 21.9 & $15.8 ; 27.8$ \\
\hline Between 1 and 8 years & 30.5 & $27.1 ; 33.8$ \\
\hline 9 or more years & 35.9 & $29.7 ; 41.9$ \\
\hline \multicolumn{3}{|l|}{ Income (Reais) } \\
\hline No income & 26.4 & $21.8 ; 30.8$ \\
\hline Up to 300 & 28.3 & $23.9 ; 32.6$ \\
\hline From 301 to 600 & 29.8 & $24.1 ; 35.5$ \\
\hline More than 600 & 36.7 & $29.8 ; 43.4$ \\
\hline \multicolumn{3}{|l|}{ Type of access } \\
\hline Only free & 4.8 & $3.0 ; 6.6$ \\
\hline Only purchased & 46.4 & $41.4 ; 51.2$ \\
\hline Mixed access & 28.5 & $23.3 ; 33.6$ \\
\hline \multicolumn{3}{|l|}{ Type of morbidity } \\
\hline Only chronic & 6 & $3.5 ; 8.4$ \\
\hline Only acute & 57.8 & $52.9 ; 62.6$ \\
\hline Chronic and acute & 25.4 & $19.5 ; 31.1$ \\
\hline \multicolumn{3}{|l|}{ Number of medications } \\
\hline 1 to 3 & 34.9 & $31.2 ; 38.6$ \\
\hline 4 to 10 & 16.6 & $12.5 ; 20.8$ \\
\hline
\end{tabular}

95\%Cl: 95\% confidence interval
The odds ratio estimates obtained by the adjusted regression model identified the risk factors as acute morbidity, consumption of up to three medications, use of medication for the central nervous system (Class N) and age less than 47 years. Free access and chronic diseases were associated with not self-medicating. The likelihood of self-medication and the adjusted evaluation of the model are presented in Tables 3 and 4 , respectively. The model correctly classified $84 \%$ of participants that did not self-medicate and $72 \%$ of those that self-medicated. The identifications were $81 \%$ correct on average. A person with acute morbidity and without free access has, on average, a $68 \%$ probability of self-medicating, while an individual with free access has a probability of $15 \%$ on average (Table 5 ).

\section{DISCUSSION}

The proportion of self-medication in the population over 40 years ( $27 \%$ to $32 \%$ ) was less reported than in other studies. In studies about the use of medicines, the recall period and distinct target populations cause different results. In a survey with elderly of all incomes, the proportion of self-medication varied from $17 \%$ in Bambuí, Southeastern Brazil, ${ }^{3}$ to $60 \%$ in Salgueiro, Northeastern. ${ }^{6} \mathrm{Haak}^{2}$ investigated self-medication in all age groups and incomes in a domestic survey of two villages in Bahia, also in Northeastern, over a period of one week in 1986, and found $74 \%$ self-medication. In the Bambui Project, Loyola-Filho et $\mathrm{al}^{3}$ found selfmedication of $46 \%$ over a period of three months. In that same study, among the age group of 40 or more years, close to $35 \%$ of individuals self-medicated. In Santa Maria, Southern, between 1994 and 1995, Vilarino et $\mathrm{al}^{9}$ found self-medication of $76 \%$ during the month before the study. A high proportion of self-medication was also found in Nepal in 2001, where Shankar et $\mathrm{al}^{8}$ reported that $59 \%$ of participants self-medicated in the six months preceding the study. The present work studied self-medication in a lower income population with 40 years or greater and a recall period different than other studies, which can explain the difference in the proportion of self-medication.

Table 3. Odds ratio from the logistic model. São Paulo, Southeastern Brazil, 2005.

\begin{tabular}{lcc}
\hline Variable & OR & $95 \% \mathrm{Cl}$ \\
\hline ATC Class N & 2.72 & $1.84 ; 3.60$ \\
Age between 40 and 47 years & 1.39 & $1.02 ; 1.76$ \\
Use of 1 to 3 medicines & 2.54 & $1.52 ; 3.56$ \\
Free access & 0.09 & $0.05 ; 0.13$ \\
Chronic morbidity & 0.24 & $0.12 ; 0.36$ \\
Acute morbidity & 3.04 & $2.09 ; 4.421$ \\
\hline
\end{tabular}

ATC: Anatomical Therapeutic Chemical; N: Nervous system; OR: Odds ratio; $95 \% \mathrm{Cl}$ : 95\% confidence interval 
Table 4. Classification matrix for discriminant analysis of two groups. São Paulo, Southeastern Brazil, 2005.

\begin{tabular}{lccccccc}
\hline & \multicolumn{3}{c}{ Self-medication predicted in the model } & \multicolumn{3}{c}{ Total } \\
Self-Medication (Actual) & \multicolumn{2}{c}{ No } & \multicolumn{2}{c}{ Yes } & \multicolumn{2}{c}{$\%$} \\
\hline No & $\mathrm{n}$ & $\%$ & $\mathrm{n}$ & $\%$ & $\mathrm{n}$ & $1,00,0$ \\
Yes & 1,185 & 84,0 & 226 & 16,0 & 1,411 & 100,0 \\
Total & 157 & 27,9 & 405 & 71,1 & 562 & 1,973 & 100,0 \\
\hline
\end{tabular}

Table 5. Probability of the participant self-medicating, by type of access, according to morbidity type. São Paulo, Southeastern Brazil, 2005.

\begin{tabular}{lcccccc}
\hline Type of access & \multicolumn{2}{c}{ Chronic } & \multicolumn{2}{c}{ Acute } & \multicolumn{2}{c}{ Chronic and Acute } \\
& Mean & Standard Deviation & Mean & Standard Deviation & Mean & Standard Deviation \\
\hline Free & 0.011 & 0.000 & 0.152 & 0.009 & 0.041 & 0.003 \\
Purchased & 0.106 & 0.003 & 0.684 & 0.008 & 0.333 & 0.011 \\
Mixed & 0.091 & 0.004 & 0.625 & 0.011 & 0.288 & 0.007 \\
\hline
\end{tabular}

The adjusted logistic model shows that the main factors associated with self-medication are age, mode of access to medication, type of morbidity and Class $\mathrm{N}$ (central nervous system) (Table 3). The study of the Bambui Project $^{3}$ about self-medication among those greater than 60 years found that the practice is more common in the 60-69 year age group, which suggests agreement with our findings that show that younger people tend to self-medicate more. According to Rozenfeld, ${ }^{5}$ self-medication among more advanced age groups can be decreased by the perception that the elderly are more susceptible to adverse events and that their clinical profiles are more delicate and require specialized accompaniment. The final adjusted logistic model proposed by Loyola-Filho et $\mathrm{al}^{4}$ also includes the variable age and obtained a similar odds ratio as the present study; i.e., the lower the age, the greater the chance of self-medication.

Free access to medicines was shown to have a protective effect on self-medication. This behavior was expected, since access to free medicine distribution programs requires physician prescriptions and chronic morbidities necessitate continual medical accompaniment (Table 3 ). The distribution of medicines and adequate health care can reduce the risks of adverse events and potential side effects from the irrational use of medications. Nonetheless, the free distribution of medicines does not guarantee their appropriate use. A survey by the Pan-American Health Organization in health units in Brazil in 2003 , found that $41 \%$ of units had weak performance in regards to patient knowledge about the use of dispensed medicines. There is a notable emphasis on the availability but not in promoting the appropriate use of these products. The same report found that the installation of the National Medicines Policy and the National Pharmaceutical Assistance Policy allowed for strengthening the regulation of medicines and the reorientation of pharmaceutical assistance, increasing its quality mainly in basic health care. Nonetheless, it found that the organization of pharmaceutical assistance service is still deficient and the process of adjusting the decentralization of the SUS is gradual. ${ }^{\mathrm{f}}$ It also identified that "weaknesses in management, in financial mechanisms and the integration of pharmaceutical assistance with health actions, often times restricts the availability of medicines, without a clear structure and organization of pharmaceutical assistance services".

The most utilized medicines are, in general, indicated for the treatment of chronic degenerative diseases, common in the age group studied.

Medicines that act on the central nervous system, such as analgesics, are utilized more among those who selfmedicate (Table 3). These results are in accordance with other work on the topic. ${ }^{1-4,6,8,9}$ Loyola-Filho et $\mathrm{al}^{3}$ found a greater used of medicines for the cardiovascular system among the elderly that did not self-medicate, which was also found in the present study. This can be explained by the high proportion of coronary disease among the age group.

Self-medication with antibiotics is a worldwide concern given the problem of developing resistant bacteria strains. ${ }^{f}$ Antibiotics in class $\mathrm{J}$ of the ATC classification were reported infrequently by participants: $8.3 \%$

\footnotetext{
e Organização Pan-Americana de Saúde. Avaliação da assistência farmacêutica no Brasil: estrutura, processo e resultados. Série medicamentos e outros insumos essenciais para a saúde. Brasília; 2005.

${ }^{f}$ World Health Organization. Antimicrobial resistance. Geneva; 2002 [cited 2006 Sep 20]. Available from: http://www.who.int/mediacentre/ factsheets/fs194/en/ [Fact sheet, 164]
} 
among those who did not self-medicate and $5.6 \%$ of those that self-medicated utilized antibiotics (Table 1). In the study by Vilarino et al, ${ }^{9}$ in Rio Grande do Sul, Southern Brazil, the use of systemic antibiotics was also low, around $4.7 \%$ for all age groups.

The current study used the database from a survey that did not directly investigate self-medication, which can lead to different results than what would be obtained in a survey specific to the theme. Nonetheless, the agreement with prior studies, in regards to both the

\section{REFERENCES}

1. Arrais PSD, Coelho HLL, Batista MCDS, Carvalho ML, Righi RE, Arnau JM. Perfil da automedicação no Brasil. Rev Saude Publica. 1997;31(1):71-7. DOI:10.1590/ S0034-89101997000100010

2. Haak H. Padrões de consumo de medicamentos em dois povoados da Bahia (Brasil). Rev Saude Publica. 1989;23(2):143-51. DOI:10.1590/S003489101989000200008

3. Loyola-Filho AI, Uchôa E, Firmo JOA, Lima-Costa MF. Estudo de base populacional sobre o consumo de medicamentos entre idosos: o Projeto Bambuí. Cad Saude Publica. 2005;21(2):545-53. DOI:10.1590/ S0102-311X2005000200021

4. Loyola-Filho Al, Uchôa E, Guerra HL, Firmo JOA, Lima-Costa MF. Prevalência e fatores associados à automedicação: resultados do projeto Bambuí. Rev Saude Publica. 2002;36(1):55-62. DOI:10.1590/ S0034-89102002000100009

5. Rozenfeld R. Prevalência, proporção, fatores associados e mau uso de medicamentos entre os idosos: uma revisão. Cad Saude Publica. 2003;19(3):717-24. DOI:10.1590/S0102$311 \times 2003000300004$ socioeconomic and demographic variables and the therapeutic class of the medicines, suggests that our findings reflect the lived reality of the patients studied. The definition of the target population in accordance with the survey objectives should be considered in order to obtain more objective and accurate responses to the questions studied. New analyses of the database utilized, as well as studies designed to understand the profile of self-medication and its associated factors would provide greater understanding of this practice in the São Paulo municipality.
6. Sá MB, Barros JAC, Sá MPBO. Automedicação em idosos na cidade de Salgueiro-PE. Rev Bras Epidemiol. 2007;10(1):75-85. DOI:10.1590/S1415790X2007000100009

7. Schenkel EP, Petrovick PR, Linck VO, Chaves CMG, Gosmann G, Costa TCTD, et al. Cuidados com os medicamentos. 3. ed. Florianópolis: Editora da Universidade Federal de Santa Catarina; 1998.

8. Shankar PR, Partha P, Shenoy N. Self-medication and non-doctor prescription practices in Pokhara Vaelley, Western Nepal: a questionary-based study. BMC Fam Pract. 2002;3:17-23. DOI:10.1186/1471-2296-3-17

9. Vilarino JF, Soares IC, Silveira CM, Rödel APP, Bortoli R, Lemos RR. Perfil da automedicação em município do Sul do Brasil, Brasil. Rev Saude Publica. 1998;32(1):43-9. DOI:10.1590/S003489101998000100006

10. World Health Organization. WHO Collaborating Centre for Drug Statistics Methodology. Guidelines for ATC classification and DDD assignment 2010. 13.ed. Oslo; 2009[cited 2010 Sep 10]. Available from: http://www.whocc.no/filearchive/ publications/2010guidelines.pdf

The study was funded by the Fundação de Amparo à Pesquisa do Estado de São Paulo (Process 2004/11920-4). Presented at the XVIII World Congress of Epidemiology, in Porto Alegre, Southern Brazil, 2008.

The authors declare that there are no conflicts of interest. 